Distinguished Professor of History at the University of California, Santa Barbara, Dr. Otis Graham is a member of the board of directors of (FAIR), the Federation for American Immigration Reform, and has been active in the population and environment movement for some time. His essay on the "Uses and Misuses of History", reprinted from The Public Historian, Vol. 8, No. 2 (Spring 1986), and (c) 1986 by the National Council on Public History, gives us the impetus and theme for this special issue of THE SOCIAL CONTRACT.

\title{
USES AND MISUSES OF HISTORY IN THE DEBATE OVER IMMIGRATION REFORM
}

By Otis L. Graham, Jr.

\begin{abstract}
In no other realm of our national life are we so hampered and stultified by the dead hand of the past as we are in this field of immigration.
\end{abstract}

\author{
-Harry S. Truman
}

The seat of the mind is in memory. -Saint Augustine

The United States entered a new era of large-scale immigration in the late $1960 \mathrm{~s}$, and in response to mounting public concern, Congress debated and almost passed a major immigration reform measure between 1981 and 1984 . The Immigration Reform and Control Act (henceforth, Simpson-Mazzoli) expired at the very beginning of the 98th Congress after agonizing and laborious months of hearings and legislative maneuvers. Though Senator Alan Simpson doggedly introduced a different measure in early 1985 for its uncertain run against the odds, it aimed at illegal immigration, leaving the legal variety for another day. It may be said that the Simpson-Mazzoli reform bill of the early $1980 \mathrm{~s}$ is now a very interesting piece of what students sometimes call "past history." 1

What advisers did the politicians call upon as they contemplated a policy response to new immigration circumstances? Reviewing the long policy debate, which actually began with an executive branch task force study in the Ford administration and carried through the Hesburgh Commission to the extensive hearings on SimpsonMazzoli, one finds Congress taking counsel from government bureaucrats drawn from the law enforcement, social welfare, and foreign policy fields; from academic demographers and economists; and, overwhelmingly, as always, from the self-selected representatives of interest groups who have a special concern with the topic. In this case, the latter were spokesmen from agri-business, labor unions, Mexican-American organizations, the immigration bar, church and philanthropic organizations, Chambers of Commerce, and any stray public interest group from population or conservation perspectives who wished to advise if not consent. This was proper, and traditional. The subject of immigration touches many aspects of human life, and requires illumination from many disciplines and social perspectives. But as one separated the subject matter into time dimensions - into references to what is past, to what is present, to what will be in the future it would be my estimate that reference to things in the past at least matched in frequency mention of current situations, and easily exceeded references to the future. What happened in the past was much alluded to by congressmen and senators, and economists, lawyers, and other expert witnesses made judgments about history. The past was abundantly engaged, but professional historians were virtually absent.

This, too, is traditional. Historians have not much noticed and almost never protested our absence from the more formal realms of policy-making. Yet our subject matter, not in the sense of ownership but of life-long professional engagement, is amply and invariably present there. History is much used in the form of its "lessons." The case under study enlarges a general finding - that such uses are most often painful misuses.

In this essay I shall attempt to demonstrate how this was so, and to suggest remedies. The latter is no simple task. If history is mis-used, should professional historians strive for a form of historic preservation, by demanding that policymakers remove their presentist hands from the body of Clio? Some may be attracted to this purist stance, but its real impact would be minimal. Another possibility is to accept the role of critic of the abuses of history in policy discussion. This seems a useful function, and may be carried out within the policymaking process, when the invitation to participate is extended, or from the sidelines. It is an important assignment, but one with a negative cast to it. Might historians also devise and advocate more positive uses? I shall offer some suggestions as to how we might move in both these 
directions, taking as a case study the debate over immigration policy reform.

This cluster of topics deserves a book-length study. Even in so bounded an arena as the 1981-84 Washington deliberations upon immigration reform, and working only with official reports and printed congressional testimony while excluding the uncharted inner hearts of policymakers where history sits as memory, an essay can hardly exhaust the matter. This essay is a small and imperfect attempt to arrive at a larger understanding of history's current and potential roles in policymaking.

There is a striking pattern in the many misconceived resorts to past experience in the immigration policy discussion of 1981-84. Misleading analogies and extrapolations almost invariably pushed the policy debate in one direction only. If the two broad poles were to regard current high immigration levels as troubling, or as no real problem - to favor less immigration, or more - then the past was drawn upon almost invariably to reinforce the position that immigration is good because it was formerly a good, and more continues to be better. What is remarkable in the published debate among policymakers is the almost uncontested assumption that history "taught" that restrictionist reforms in the $1980 \mathrm{~s}$ should be defeated.

This is a mis-use of history and a matter to which I shall return. But was it influential in policymaking? Some have answered in the negative, arguing that politicians make reference to history only to "provide an aura of intellectual authority for a position already decided." ${ }^{2}$ Surely there is some truth in this assertion, but my experience in immigration discussions suggests that it goes too far. There are many reasons why Simpson-Mazzoli failed to be enacted by the $97 \mathrm{th}$ and $98 \mathrm{th}$ Congresses, and why it took the forms presented to the full senate $(1982$, 1983) and House (1984) as an inadequate piece of legislation falling far short of restoring national control of immigration to the U.S. A major reason was the nature of our political and legislative system, which does not deal well with a social problem in which the public interest and public sentiment point in one direction, while the interest groups who show up for their part in the dance of legislation prefer the status quo and play the veto role. This is especially true when the president tends to shun the issue, as Reagan has done. Many other reasons for the failure to enact reform might be suggested, and Senator Simpson himself appears to have concluded that this "comprehensive" strategy was wrong, too many issues splitting a potential consensus. Convictions and fears had much influence - that employer sanctions might encourage discrimination, or that certain employers might have to pay higher wages. But analysts have ignored another major cause both of the measure's failure and also of its progressive dilution as it went forward, so that by late 1984 it deserved neither the hopes of its advocates nor the anxieties of its opponents. This factor was history, as employed.

History was made to be a strong influence for delay, for obscuring the size of the problem, for obstructing or discrediting avenues of policy which might bring effective remedy. If explicit references to (let alone the unconscious influence of) history's lessons had been prohibited entirely, Simpson-Mazzoli would surely have progressed more quickly and in a more restrictionist version, as national opinion clearly has desired throughout the debate. A misapplied past has made our national future more difficult by helping to confuse the policy process.

Let us recall the policy situation. Legal immigration into the U.S. in the decades between 1924 and 1965 reform acts has fluctuated greatly, but the average annual total over those years was $191,000 .{ }^{3}$ Totals in that range made a modest demographic and economic impact. But change was under way. In the postwar era, the U.S. became the world's most attractive and open society, a nation with a vibrantly expanding economy, a growing commitment to cultural and racial pluralism, and minimal enforcement of immigration laws. Even as the U.S. passed through the Civil Rights movement and the second full decade of postwar economic prosperity, mankind entered an era of unprecedented population increase which came mostly in the underdeveloped, impoverished parts of the globe.

As the human population became rapidly more numerous while yet disproportionately poor, enhanced global communication and transportation facilities loosened the ties of locality. The postwar era was thus a time unlike any that humanity had ever experienced. A burst of global population growth outraced economic development in many societies of the Third and Fourth Worlds, expanding both human numbers and human misery. Migration, always a feature of human life and an individual solution to hardship, quickened in the late $1960 \mathrm{~s}$ and through succeeding decades. Both in the Mediterranean region and in this hemisphere, the pattern of movement was from south to north.

In these circumstances the only First World society with a 2,000 mile border touching the Third World, the U.S. recorded a surge of migration pressures. These pressures came to bear upon a nation with an under-funded immigration agency (the Immigration and Naturalization Service, INS) attempting now to enforce the new 1965 revision of the basic immigration code. This "most thoughtless of the many acts of the 
Great Society," in Theodore White's words, had inadvertently loosened the controls on refugee admissions and made family reunification the vastly dominant factor in selection, replacing the occupational focus of earlier law. ${ }^{4}$

After 1965, U.S. immigration policy selected primarily on the basis of nepotism. Legal admissions unexpectedly tilted strongly toward Latin America and Asia, and a surge of nonquota legal immigrants revealed that there was no ceiling on annual admissions. Legal immigration totals averaged about 440,000 in the 1966-79 period, reached 800,000 by 1980 , then eased back to just below 600,000 annually. Legal immigration had tripled from the 1921-65 norm. Illegal immigration also greatly increased, and though it cannot successfully be measured any more than tax evasion, estimated conservatively it probably ran at totals higher than 500,000 throughout the $1970 \mathrm{~s}$ and into the $1980 \mathrm{~s}$.

Thus arrived a new context for immigration policy. Immigration is no longer an insignificant element in American life, as it seemed in the four decades following the 1921 restriction. It is now responsible for 40-50 percent of American population growth, and the proportion will go higher as domestic birth rates remain below replacement level. Immigration policy has suddenly become population policy, and dictates an expansion which would have no end if current trends are extrapolated. Prior to a recent study by Leon Bouvier of the Population Reference Bureau, most observers accepted Census Bureau projections that the U.S. population will stabilize around 265 million in twenty to forty years. Bouvier adds the immigration factor. If we continue to admit 1 million (net) immigrants a year (the current rate is probably higher), and assuming a total fertility rate of 2.0, the U.S. population will reach 409 million in 100 years, and will still be growing. Yet a 2.0 TFR is below replacement level! These glimpses of possible futures come after a national population commission concluded that America would benefit from an early stabilization of population, a desire shared by most of the public. 6

This enormous demographic impact of current immigration levels was the most important result of the status quo. Since Americans are demographically illiterate, this was not the impact which most attracted notice. There was rising concern about the displacement of American workers in a time of unusually high unemployment. But how much displacement, and where? The matter was complex, but the weight of evidence disheartening. Illegal aliens were displacing American workers in a broad variety of desirable jobs, ranging from construction work in Houston to painting the statue of Liberty. They, of course, also filled "undesirable" jobs, menial occupations, which would not be upgraded in wages or status so long as Third-World manpower was available. The chief victim of the job competition between citizens and illegal aliens was the American black, caught disproportionately in the bottom third of the labor market. In the words of David North and Allen LeBel, in a study for the National Manpower Commission, "large-scale illegal immigration depresses wages, prevents change in the secondary labor market, and results in the creation of a two-class society." 7 These demographic and labor-market impacts were quite clear in their main outlines. Slightly less clear were the impacts of large-scale immigration on public sector fiscal prospects. No one doubted that it cost governments much money to admit refugees on any scale, let alone the large number of recent years. But illegal aliens? Early studies indicated that they paid more in taxes than they took out in social benefits. Careful recalculations revealed that illegal aliens represented a moderate to heavy drain upon public services by the end of the 1970s, as the new residents learned of their entitlements. ${ }^{8}$ An Urban Institute study of immigrants in California found that "state expenditures for public services used by Mexican immigrants have not been offset by taxes paid by this immigrant group," reversing earlier and less thorough studies. ${ }^{9}$

Apart from questions of the demographic impact of current immigration (which was to make America more populated and add to its demographic momentum), labor-market impacts (which were to displace at least some American workers and depress wage scales for others), and fiscal impacts (which were negative and painful for Los Angeles County but difficult to calculate for the U. S. Treasury), there was the question of the larger economic impact. Did immigration contribute to economic growth? This was a historical question as well as a theoretical one. Some argued that large-scale immigration was a cause of the economic growth we had experienced over three centuries, and that "there is no reason to believe that what was true in 1880 or 1910 or 1924 has suddenly ceased to be true in 1980."10 This simplistic view was widespread, but deeper thought carried others to quite different conclusions. Leading scholars concluded that the economy in the twentieth century - specifically, in the 1920s - had strengthened when immigration was cut off. Sometimes a national economy needs immigration of a certain size and type to assist in desirable growth patterns; sometimes it does not seem to need much immigration at all. But at issue was the future. No one saw it clearly, yet the U.S. economy was evidently shifting rapidly away from its old industrial base toward a more capital-intensive, information-andservice base, constrained increasingly by resource shortages and pollution effects. In such a future, it was difficult to justify immigration policies which brought largely 
unskilled labor to the U.S. in the 1980s and had virtually no tie to labor market considerations, whatever they might turn out to be. ${ }^{11}$

Whatever the impacts, immigrants continued to walk, wade, and fly, into the U.S. in large numbers as the 1970s gave way to the 1980s. The nation's control system virtually broke down. The INS was swamped by its workload, unable to keep track of students or other visa recipients, its record-keeping a nightmare, its field enforcement personnel plainly unequal to the task of border or entrepot control. If large-scale immigration was a good thing, America was a blessed country; for in the $1970 \mathrm{~s}$ and 1980s, this was our lot. Immigration now virtually decided the nation's eventual population total, not domestic birth and death rates. It exerted a major influence upon racial, ethnic, and religious makeup, languages, social cohesion, the structure of the economy, and the progress of domestic minority groups. ${ }^{12}$

With a power to transform the nation which was not matched by many social developments, immigration, doubling and tripling within legal categories and spilling over into a major extra-legal phenomenon, could have avoided being seen as a leading public issue only if its effects were widely perceived as benign. Experts would divide on this question, but the American public was remarkably undivided. Polls invariably showed that the public wished less immigration on the legal side, and an end to illegal entry. A Roper poll of June 1980 found 80 percent of respondents agreeing that the U.S. should "reduce the...number of legal immigrants who can enter the U.S. each year," 91 percent of respondents in a 1980 Roper Poll wanted the U.S. "to make an allout effort to stop the illegal entry into the U.S. of the...foreigners who don't have visas," and Gallup polls in 1984 found that 3 in 4 Americans "favor a law that would prohibit employers from hiring immigrants who have entered the country 'without proper identification'." The concept of employer sanctions, central to Simpson-Mazzoli, was favored by 79 percent of Gallup respondents in 1983, while more than six in ten people said that everyone in the U.S. should be required "to carry an identification card such as a social Security card." 13

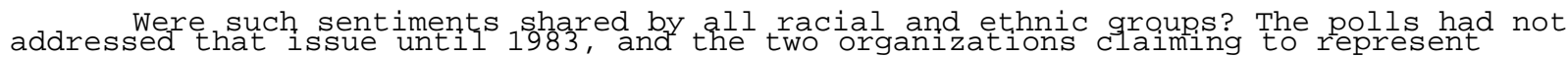
Hispanic interests and sentiment had repeatedly asserted in hearings on immigration that Hispanics opposed employer sanctions and were not supporters of reforms which limited either legal or illegal immigration. But surveys in 1983-84 of Hispanics generally and of Cubans in Miami revealed that substantial majorities of both Hispanics and blacks favored penalties on employers hiring illegal aliens and increased funding for the Border Patrol, while believing that illegal aliens take jobs from American workers. Asked if immigration laws should be tougher, 70 percent of blacks and 55 percent of Hispanic citizens agreed, according to a pioneering poll taken by $V$. Lance Torrance and Peter Hart in 1983. ${ }^{14}$

In the 1980s these public sentiments developed into a reform movement and the Simpson-Mazzoli bill was the legislative result, carrying the hopes of all but the most uncompromising restrictionists. In the policy discussion surrounding this complex issue, one would not have expected history to be much involved. The problem of immigration was a current and a future one, and the central questions were: What were the numbers? What were the impacts and implications? What should be done? If American policymaking were a black box of rationality, it might resemble the thinking processes of Senator Alan Simpson of Wyoming. He did not know much about immigration when his service on the Hesburgh Commission began. He educated himself, and concluded what any rational person would conclude: legal and illegal immigration had in absolute numbers reached levels higher than the decades before World War I, and the inflow would continue far into the twenty-first century unless something were done; the economic and social implications of such an influx of people were negative to the national welfare, on balance, so that restriction was imperative. ${ }^{15}$

This decided, the main outlines of reform were clear, though reasonable people would differ on the details. Legal immigration must be reconsidered, especially the absence of any effective ceiling, as well as the desirability of moderating the bias of the 1965 system toward reuniting families, which had replaced four decades of labor market primacy in U.S. policy, thus allowing the desires of individuals rather than national economic interest to shape basic policy. The considerable confusion in refugee and asylum matters must be addressed. Illegal immigration must be greatly reduced, through some combination of enforceable employer sanctions, increased INS staffing, and perhaps overseas developmental and population control assistance.

If democratic opinion were mirrored in legislative outcomes, immigration reform would have come in the 1980s in the form of steps to reduce overall levels of immigration, restoring the integrity of the nation's disintegrating system for limiting and selecting as foreigners pressed for citizenship. The best means to these ends would, of course, not be nearly so clear. How to enforce an employer sanction law? Whether and how to offer amnesty? Within legal totals, how to apportion the claims of national labor needs, individual desires for family reunification on U.S. soil, humanitarian relief? But the main goal of legislative reform would be clear - 
toward policy that was more restrictive and then enforced. To arrive at this conclusion, one need not resort to the "lessons" of history.

This was not the result of the 1981-84 battles over Simpson-Mazzoli. What the policy machinery produced was not what either Simpson or Mazzoli originally intended, and while this is the norm in American policymaking, the string of compromises had led to generic difference. Simpson-Mazzoli, if enacted in its last 1984 version. would have increased legal immigration, and failed to place a ceiling on it, failed to enact enforceable controls on illegal immigration, and granted a generous amnesty which would have increased both legal and illegal immigration even above the levels of $1984 .{ }^{16}$

How to account for this failure of nearly a decade of reform efforts? How did an effort to control immigration become stripped of virtually all significant restrictionist features but employer sanctions (not backed by a credible enforcement process), while taking on expansionist features in the form of a large amnesty, an experimental guestworker program not confined to agriculture, and enlarged legal admissions? The answer is complex, and one hopes that a comprehensive legislative history will be produced soon. Among the factors frustrating reform is a newcomer to policy literature, an unusual, lifeless culprit - the past, as remembered and dragooned into service.

There is space for only the briefest sketch of the role to which history was assigned, working from evidence provided by the official record. The testimony of the past was repeatedly said to be this: The voices of restrictionism have been heard in the land before, and the nation should not have listened. What history taught was the moral illegitimacy and practical obtuseness of the earlier restrictionist movement. "It is a shameful truth," said one historian, "that historically racism has been the most potent single force in shaping U.S. immigration policy." 17 So much for the restrictionist impulse, damned out of history. They had all been bigots. They had also agitated about a non-problem, for another lesson of our past was that immigration did not bring problems but was an unalloyed benefit. "There has been an underlying suggestion today that...the numbers are too high, the impact undesirable..." said Senator Kennedy in 1983. "But as I have said repeatedly...these implications fly in the face of American history and all that we know about the contribution of immigrants to our society."18 The economist-turned-historian John Kenneth Galbraith declared: "The one thing, however, that we know from all historical experience is that the demand for workers increases with the supply of workers." Immigration always drives an economy upward; it was natural for Americans thus to interpret history. ${ }^{19}$

To Father Hesburgh, not only did history teach that immigration had always helped America and therefore always would ("Enlarged immigration is good for America. It is part of our heritage") but historians had so informed the select Commission. As Hesburgh wrote in the Select Commission's report:

Historians, in their support of increased immigration,

have cautioned against overly restrictionist tenden-

cies. They point out that U.S. citizens have always

been concerned about the arrival of immigrants but

note that immigrants have always made contributions to U.S. society. ${ }^{20}$

It is not clear who these "historians" were. But to Hesburgh, "the historians" had spoken, and had counselled that reform in the $1980 \mathrm{~s}$ must lead to larger numbers of legal immigrants.

Beyond the lessons that restrictionism came from morally illegitimate sources and that immigration always and in all ways was an unalloyed benefit, policymakers claimed to learn from the past that the meaning of America, its sense of purpose and of destiny, was not just embodied in but intertwined with and dependent upon largescale immigration. "History teaches," said Senator Gary Hart as he worked to expand the numbers of refugees given asylum, "that many of the Europeans who settled this continent braved unimaginable hardships... We must continue to serve as the Canaan for those today who suffer under the same misrule against which our ancestors rebelled. Each grant of asylum reaffirms this nation's commitment to the fundamental principle we hold most sacred." ${ }^{1}$ "Keeping our doors open within reason to the peoples of the world," said Hesburgh, "is an all-important way to renew and maintain the forces and values that have made the U.S. the great democracy and world leader that we are....It is important that this vital inflow continue." To fail to expand immigration in these days, Father Hesburgh reasoned, "would be a betrayal of what is best in us, what the country stands for above all else - opportunity, freedom, and respect to diversity...."22 But my nomination for the most muddled non-sequitur goes to one Donald Hohl of the U.S. Catholic Conference, who told a Congressional panel in 1982:

We feel it worthy of our time to review the historic sequences of the changes in our laws and some of the arguments which were eventually persuasive in accomplishing reform, for today we hear once again the lament that the new immigration threatens to change the social, 
cultural, and even linguistic profile of our society. The implication is that America as a whole will be a worse nation for it. After all, wasn't this the judgment passed by settled groups on each substantial wave of immigration? Let us learn from the past and not repeat our errors in the future. ${ }^{23}$

This translates as: It was a mistake, in the past to restrict immigration. If one hears suggestions that immigration flows be restricted, they must be similarly mistaken.

What might historians have said of these many uses of the past in the legislative history of Simpson-Mazzoli? On this question there is some direct evidence. Historians, broadly defined as those whose principal occupational pursuit is the study of the past, appear to have been marginally involved in the study of the problem and the devising of contemporary solutions. Father Hesburgh affirmed that "historians...have cautioned against overly restrictionist tendencies," and presumably concurred in the Hesburgh Commission's decision to enlarge legal immigration totals. Hesburgh did not identify these "historians," but we know that he valued the contributions of that craft. He hired Lawrence Fuchs, a scholar with a Ph.D. in American government, as staff director. Fuchs laudably commissioned several historical studies for the edification of the commission members, who may or may not have read them. ${ }^{24}$ The staff report which accompanied the commission's Final Report opened with a historical section, and indeed the second word in the Final Report is "history." Surely this reflects the orientation of Fuchs, and the one staff member with professional training in history, Susan Forbes. Beyond this point, the profession's direct involvement dropped close to zero. Of the approximately 175 persons consulting with the commission as it travelled about the country, I counted only one historian.

This was, however, a great deal of professional advice when one compares it with the congressional hearings record of 1982-84, where experts and other citizens make their public contribution to policy. In this voluminous record, I found testimony by only two historians, one not a historian of immigration at all, and neither invited qua historian but as a spokesman for interested organizations. If the subject were acid rain, Congress would invite and presumably respect expert witnesses, and not issue an open invitation for all citizens to offer testimony because each had experienced weather. Experiencing weather does not make one an expert on climate; driving a car does not make one an expert on transportation. But being human made everyone participating in the immigration debate a specialist in interpreting the meaning of history on that issue. If Everyman is his own historian, who needs the professionals?

Some may think it a bit of good luck that we historians are not consulted in matters of policy, which are after all efforts to peer into and manipulate the future. Other academic experts, serving as court witnesses or legislative consultants, have been accustomed to contradicting each other. This has been especially embarrassing, professionally, to psychologists. More troubling, historians, who are surely the most tentative and ambiguity-tolerating of all those practicing in or near the broad area of the social sciences, might become excited by the prospects of secular influence. We might turn out to be, or learn to be, believers in what might be called the hardapplied analogy. If those in authority want formulas, Dos and Don'ts, we might be lured far from our philosophical moorings by the persuasion of influence rather than ratiocination.

These are real concerns, but those who see merit in our traditional isolation have surely misjudged the point of innocence. Historians who write in immigration have already influenced policymakers and the general public, some of whom are surprisingly literate, and this is true throughout a range of human activities from arms control to zoos. Most of what people remember was not experienced but taught, transmitted. Historians are more influential transmitters and teachers than they may think. To pursue our particular concern, references to the lessons of history on immigration issues were rarely, in the debate of the early 1980s, based upon memory. The impact of decades of unlimited non-Asian immigration, the quality of the Dillingham Report, the furor over the restrictive laws of 1921 and 1924, even something so recent as the Bracero program - these were influential memories, but almost no policymaker claimed to have experienced them directly. Interpretation was based upon some hazy recollection of what was learned from Handlin, or Higham, or some text. Our profession is already mixed up in the policy game.

How might we improve upon this engagement with policy? I remain dubious about explicit policy choices coming with the endorsement of "history's lessons," whoever brings them forward. Most of our advice should bear upon the process of analysis. One might say that there are at least three stages in the professional historian's advice, and the first is negative, the admonition to stop thinking in a certain way. The other two are more positive.

It should first be the historian's task to warn that analogizing is usually a 
mis-use of history. Here the layman requires some elementary wisdom. Situations are never exactly the same. An example of brilliant success or disastrous failure is easy to lift from the historical record, but this is no substitute for analysis, and is often harmful. Historians above all others should advise great skepticism about analogies, and encourage a critical response to their entry into the discussion in the usual unchallenged way. There is much in the epigram, "One cannot step in the same river twice." That situations always change is a cliche, but one which explains why so many of the "lessons of history" deserve a cold eye from those who would shape the future.

One problem with analogies is that you may have them wrong, especially if cobbled together out of a layman's memory or distant reading. As a case in point, take the restrictionist impulse of the 1890s-1920s. It cannot simply be stigmatized as racist and alarmist, though there was far too much of that. Restrictionism attracted some of the best minds in America, including many liberal clergymen, spokesmen for organized labor and the black community, and socialists. The case for restrictionism had a Leftist heritage as well as Rightist one, which was unsurprising, since the impact of unlimited immigration fell most heavily upon America's working classes. The World War I era restrictionist impulse was indeed laced with much xenophobia, yet drawing an analogy from that time to the $1980 \mathrm{~s}$ is simply insupportable. The Immigration Restriction League of the early twentieth century, led intellectually by racists like Captain John B. Trevor and Madison Grant, was vastly different in assumptions and argument from the leading restrictionist organization of today, the Federation for American Immigration Reform. In the 1970s and 1980s, the case for immigration reform in the direction of stricter enforcement and thus for a restriction of entering numbers was strong enough to convince two presidential task forces, one national commission, 80 U.S. senators in 1982 and 76 in 1984, and was made entirely without the sort of racist or ethnic appeals so prominent fifty years earlier.

A distorted version of history also underlay the interpretation of what immigration has meant to American society in the decades prior to restriction. History was said to reveal a simple story, that mass immigration produced unalloyed benefits economic growth and creative, law-abiding people like your grandparents and mine. There is truth in such statements, which are a part of a larger reality. Costs came with the benefits. Immigration displaced blacks from jobs and entire communities where they had established a foothold. It sharpened ethnic and racial conflict, and produced new interest groups whose influences on American foreign policy discussions were not always helpful in charting the best path ahead. Immigration on a virtually unlimited scale had skewed income distribution in a regressive direction, and restricting it in the 1920s permitted a trend the other way. ${ }^{26}$ The distinguished historian John Higham, whose seminal Strangers in the Land (1956) told us so much about nativist impulses which were a part of the motivation for restriction, has written in apparently unread passages that restrictionism arose also from real grievances having nothing to do with racial or ethnic dislike. ${ }^{27}$ The debate over restriction, as Michael Teitelbaum wrote in Foreign Affairs recently, "is a contest of 'right' versus 'right' and always has been." 28

Even when some episode out of the past is studied with a care and respect for complexity which policymakers do not appear to think necessary, and even assuming that one could draw reasonably consensual lessons about what contemporaries should have done or not done (and not all serious students will agree even on that), an analogy is a way od transporting dangerous cargo. For times and circumstances change especially rapidly in modern America. "Our circumstances have changed," one of the two historians to testify told a bored congressional panel in 1982, "the future is not what it used to be." The case for restriction does not derive from the past, but becomes stronger when decoupled from it: "Restrictionism begins with the recognition that immigration is a solution to human problems which, though it seems to have worked for our ancestors and for us a very different demographic and ecological time, increasingly becomes only a temporary solution and only for a very few." ${ }^{29}$ Michael Teitelbaum of the Ford Foundation wrote in 1980: "Today...the U.S. situation is unique both in world terms and in terms of our own history." 30

This first assignment of historians who would engage policymaking, to convey skepticism about analogies, was so taken to heart by a colleague I recently encountered at a professional meeting that he declared his disinclination to tell Congress anything at all if they were to ask about his area of specialization (which happened to be immigration). His expertise was in the issues of another era, he maintained, far removed from the changed circumstances of today. This seems a prudent view with which I have some sympathy, but I think it not the last word. Perhaps there is some use after all for carefully disciplined analogical thinking, an area where we have much work to do. When some historical episode is close in time, thus shaped by currents similar to our own, it seems a mistake not to ponder its contemporary bearing. Take the issue, within the larger Simpson-Mazzoli framework, of "amnesty," or as some prefer, legalization of illegals already here. Commendably, the European and Canadian experiences with amnesties were the subject of careful study, and found to 
impart a discouraging message to the supporters of this unprecedented (in U.S. immigration policy) stroke-of-the-pen solution to the presence of illegal aliens. It appears from the history of recent amnesties abroad that they do not reach the target population adequately, and have to be repeated. Historical analogies in this case suggested that Simpson-Mazzoli become a somewhat narrower gate, dropping the idea of amnesty altogether as unlikely to achieve its ends and objectionable on other grounds. These "lessons" of experience abroad were ignored, or at least given little weight, and amnesty was a part of the final Simpson-Mazzoli measure all the way to its 1984 demise. ${ }^{31}$

The same result obtained in the issue of the guestworker program. Such a program, either in the form of a controlled work force in agriculture or a foreign worker contingent which is free to roam the nation for "jobs Americans don't want," was often proposed as the debate went on. The Hesburgh Commission paid attention to European experience with gastarbeiter as well as the Bracero program of the forties and fifties, and found that the studies produced unambiguous "lessons." As tried in Europe within the past fifteen years, guestworker programs briefly solved immediate labor supply shortages, but at a high price in social tensions and service costs from alien populations which expanded from workers to families and took on permanency. The host European governments abandoned the programs, and even now strive unsuccessfully to entice the immigrants to emigrate. Alan Simpson concluded: "The Senate...rejected a guestworker program.... If the European experience is any example - and it is one we watched closely in our debate and in our hearings - this will result in claims of equities to justify the workers' right to remain in the country." ${ }^{2}$

This pondering of relevant history appeared briefly to influence U.S. policymakers away from the guestworker option. Both the commission and the original Simpson-Mazzoli drafts rejected the idea. Some witnesses made much of this version of history. Arnold Torres of LULAC commented: "We look back at the congressional history of how previous temporary worker programs were developed in the $1920 \mathrm{~s}$ and the $1940 \mathrm{~s} .$. the abuses were rampant. We kind of feel as though history is repeating itself." ${ }^{33}$ Professor Mark Miller told the Senate that "careful examination of past U.S. experience with temporary foreign workers policy and of comparative policies in western Europe reveals an uncanny history of...policy resulting in problems more so than serving the public interest...." ${ }^{34}$

Yet here, as in the amnesty issue, historical analogies had little power when they pointed toward the need for restriction. The historical lessons weighing against a guestworker program were, as with the amnesty, eventually overridden by other considerations. On the floor of the Senate, Simpson was forced to accept a guestworker program. Analogies which appeared to support restriction were somehow ineffective, and were given little weight. Yet these were the analogies to more recent experience, and therefore arguably of more policy utility than all of the harking back to the Statue of Liberty or the "lessons" of 1921. If all analogies may not be banned from policy discourse, then one hopes that historians will develop skills as critics of the analogic technique as applied to calculations of what to do about tomorrow.

Thus the immigration policy debate suggests a two-fold assignment for historians as they confront the layman's favorite substitute for thinking, analogizing. First, historians must ceaselessly warn against the facile use of past example as a source of policy formulas. At the same time, those of us who have not thrown up our hands in despair that analogizing can ever be anything but a source of error (a position toward which I admit some attraction) must work to clarify and apply guidelines for the rigorous and cautious appropriation of the "lessons" which past episodes may contain for similar problems in our present. One prudent guideline might be the suggestion that analogous situations in the past be searched more eagerly for questions than for answers.

But disciplining the use of analogies, as vital as it may be, is a form of policy device which does not, to my mind, reach the historian's full potential. The most valuable assistance we bring should be analytical, to supply the historical perspectives special to our craft.

Those who appeal for historical perspective mean many different things by the phrase. A central meaning conveys the act of pulling far enough away from the immediate subject and surroundings to see the present in its true form and draw whatever conclusions derive from that angle of vision. It is often assumed that this will bring a certain calm amid the alarums of today. This seems to me only one possible result; on

occasion, that perspective might produce a heightened sense of anxiety! John Kennedy, during the Cuban Missile Crisis, was not calmed by what he had learned from reading Barbara Tuchman. But there is much more to historical perspective than its capacity to nurture, by turns, philosophic detachment or a revived awareness of peril.

Let us return to our case. Those steeped in history would place the immigration issues of today in a long frame of reference, and then might say any number of useful things to contemporaries. They might remind us that mass migrations cut deep channels, 
as migrants relay information and aid along family chains. Immigration thus builds momentum; current flows will be harder to curb the longer they are uninterrupted, if one assumes unchanged push-pull dynamics. Or they might comment that newcomers are always resented by settled residents, usually for a mix of justifiable and meanspirited reasons. Or, they might remind others that predictions of economic calamity in the event of the curtailment of access to a low-wage population have been made many times by those who use that labor. In the most important of such instances within the last century - slavery in the South, and child labor in industry - the economy adjusted nicely to the sudden need to get the work done by others. Or, it might well be noted that the U.S.-Mexican border has a very different meaning to Mexicans than to gringos who in the mid-nineteenth century established it far south of its original position. And I much like the historical perspective offered in this comment on Simpson-Mazzoli by the historian John Higham, in a letter to the editor of the New York Times in 1984:

The clamor against the Simpson-Mazzoli bill today closely resembles the rigid opposition in the first decade of the twentieth century to any scheme of immigration restriction. The inescapable need for some rational control over the volume of immigration in an increasingly crowded world was plain to see, then as now. But unyielding resistance from the newer immigrant groups, from business interests that exploited them, and from the traditionalists who feared any increase in the powers of government, blocked all action. The problem was allowed to fester and grow -until a wave of national hysteria brought into being a system that was extravagantly protective and demeaningly racist. Hispanic leaders, chambers of commerce, and civil libertarians should take note. ${ }^{35}$

These examples suggest some of the fruits of historical perspective, when by this we mean the habit of placing the eye where the long sweeps of time cradle the contemporary event, allowing patterns of similarity and dissimilarity in situation and context to take on clearer outline.

There is yet another meaning of the term "historical perspective" which seems even more useful to policymakers. An analytical asset which comes from thinking historically consists of the application of those characteristic modes of thought inherent in the historical enterprise at its best. These constitute a special sensitivity and skill in two dimensions of human life - the dimensions of time and of context, which might also be called the diachronic and the synchronic, after Robert Berkhofer's usage, or sequence and setting, even the vertical and the horizontal. ${ }^{36}$

The first dimension derives from our profession's central preoccupation, change, and continuity over time. As Lawrence Veysey put it recently, "an overriding concern for temporality distinguishes the historian from academics of all other persuasions except astronomers, earth scientists, and some biologists, who might be called the historians of nature." ${ }^{37}$ Where are we in the stream of time? Historians push that question to the front of the discussion. If we develop skill at anything, it is in the ability to discern which parts of the received heritage of any contemporary moment retain or even gain in force and momentum, and which tend toward debility. Every moment is composed of strands from the past, but these are never of equal vitality. Reasoning by simple analogy confers on every part of the inherited past the same force and effect they possessed when they last meshed in some apparently similar situation long ago. Historians know that time enervates and initiates as it moves, that it undermines many a fighting faith before that is fully known, and launches new forces of unsuspected power. As we work with time, we ceaselessly strive to discern where the hand of heritage is heavy and where light, where time has brought change. We have not forgotten the words of the Episcopal hymn, "new occasions teach new duties, time makes ancient good uncouth."

The second dimension derives from the discipline's passion to see things whole. Economists think that price drives Man, sociologists look to social structure, philosophers to ideas, political scientists to the state. But historians mesh them all, adding geography, climate, disease, and the ever-confounding roles of exceptional individuals and of accident. We may often honor our assignment at contextual reconstruction in the breach, but our discipline is inherently holistic and nurtures the contextual perspective.

Where might this lead, in counselling immigration policymakers in the 1980s? Like economists, six historians might well have given seven answers (along with some principled abstentions, on the ground that what historians know "does not apply"). But a certain testimony flows from the analysis to this point. First: Beware analogy. In immigration matters (and in much else), the pre-World War II past is mostly irrelevant to present circumstances. Analogies often mislead when seen as a repository of policy formulas, failed or successful, though they may prove helpful as sources of wisdom and 
insight. In any event, analogies drawn from occasions near to our own time are likely to prove less misleading.

A second communication rings with a more positive spirit, and advises the donning of the lenses of time and context. This essay has suggested how these analytical perspectives lead to a clearer perception that the national craft has moved out upon new waters, requiring a restrictionist resolve in our immigration affairs which substantially departs from attitudes and practices appropriate to an earlier time.

"I am not a historian. I wish I were," said Congressman Ron Mazzoli, "because this subject we are into involves history." 38 One understands his wish, for indeed the subject was saturated with references to the past, and was powerfully shaped by group memory. Judging only by the rhetoric, the past was much involved in the U.S. government's decision, in 1981-84, that it would bring a certain set of reform proposals to a floor vote in the legislature, and then would not change the status quo at all. Surrounded by emotions and maxims derived out of history, Mazzoli understandably wished to be a historian in order to sort it all out. Historians were not ready to be of much help, in the sense that there is no mature literature on the uses and misuses of history in policymaking. Unguided, Mazzoli and his colleagues did as they wished with the past.

What are we to make of this instance? We find the past mostly drawn upon, and apparently most effectively drawn upon, by the opponents of policy change. In the early 1980s, the past was made to confer legitimacy upon a virtual open door to migrating peoples, since that had brought us all here and endowed this nation with a moral superiority denied to more ordinary societies. History laid a moral incubus upon the very idea of restriction upon free entry, an idea stained by association with bigoted men alarmed about a non-problem. Historic memories made the American Jew an instinctive opponent of immigration curbs and gave some Hispanics a deep wariness about any discussion of a policy area somehow associated with WASP nativism. Thus was history made to serve as one of the obstacles to a policy revision which was and remains long overdue.

Have we uncovered a trail toward some general rule, the past tending to lend itself to conservative (in the sense of preserving the policy status quo) purposes? Contrary evidence comes readily to mind. Immigration as a policy topic presents unusual peculiarities. It is not often that a contemporary policy reform bears some resemblance to a course of action that had "already been tried" sixty years before, and this earlier reform had come to be remembered (historians were crucially active in shaping this recollection) as somehow disreputable in motive and some sort of mistake. And one can quickly call to mind radical departures in public policy for which the official rationale was essentially historical - Harry Truman's decision to intervene in Korea, Hitler and Mussolini"s expansionism in the 1930s, even "the Reagan Revolution" of 1981-198?.

Thus it would not appear that the past is consistently lending itself to a role as opposer of each and every sharp policy redirection. Yet perhaps the Simpson-Mazzoli case is indeed a clue to something larger. At least in our own immediate era, and in domestic policy, the past, as remembered by participants in policymaking broadly conceived, appears to function as one source of resistance to two sorts of policy revision in particular. History is effectively deployed against suggestions that the government undertake a more active social role. This function of the "lessons of the past" is a recent one. The situation was quite the reverse when John Kennedy came to the White House, and the pattern will presumably continue to prove unstable. A more durable pattern may possibly be discerned as one ponders the immigration debate, suggesting that the past seems also to be called upon frequently and with apparent effectiveness to impede or discredit policy change which partially or wholly repudiates and departs from traditional moral assumptions. Amid confusing and changing circumstances the past seems to lend itself especially well to the needs of those who resist policy changes involving moral and ethical re-evaluation.

These observations pertain to the history in the heads of the laity. In one other sense is the influence of history likely to slant, in the contemporary era, toward resistance to policy change. To the degree that the historical profession shapes the public mind, or comes to bear more directly upon the policy process itself, it will be the influence of a profession on the whole suspicious of generalization, telling a tale of complexity, unpredictability, surprise, contingency, unanticipated consequences. The currents of this mindset move against many craft - armadas of foreign or domestic adventurism, to be sure, but also the many smaller, useful expeditions leaving old policy habitations for newer, more promising ones.

Reform of immigration law toward stricter controls in an important sense redefines the nation. This is a wrenching and difficult experience, and in an effort to postpone it, the past has been brought into play to discourage fresh thought and candid reassessment. History has been given the form of ideology, to make judgment inflexible. One lesson only from our past seems unambiguous, consensual, and entirely 
useful in this immigration matter. It is summed up by Alan Simpson, who came up with it himself, without help from the experts: "This nation of ours has been historically and consistently ambivalent about enforcing its immigration laws." ${ }^{39}$ Amen, Senator, go to the head of the class.

NOTES 